\title{
ANALISIS FLYPAPER EFFECT PAD DAN DAU TERHADAP BELANJA DAERAH DI PROVINSI KALIMANTAN TIMUR TAHUN 2010-2014
}

\author{
Aisyah Najibah Nabilah \\ Aris Soelistyo \\ Hendra Kusuma \\ Ilmu Ekonomi dan Studi Pembangunan Universitas Muhammadiyah Malang \\ Email: aisyahnn10@gmail.com
}

\begin{abstract}
This research purposed to know the effect of PAD and DAU toward regional expenditure in the country/city in East Kalimantan province and to know whether flypaper occur in the country/City of East Kalimantan Province in the 2010-2014. The instrument used in this research was the analysis of data panel regression. The results of this research showed that the local revenue (PAD) and (DAU) was took effect regional expenditure significantly. PAD took effect DAU toward regional expenditure, but DAU did not affect significant toward regional expenditure. During the period of this research did not happen flypaper in country/cityinthe ProvinceofEastKalimantan.
\end{abstract}

Keywords: The Local Revenue (PAD), The General Allocation Fund (DAU), Regional Expenditure, and Flypaper Effect

\begin{abstract}
Abstrak
Tujuan dari penelitian ini adalah untuk mengetahui pengaruh PAD dan DAU terhadap belanja daerah pada Kabupaten/Kota di Provinsi Kalimantan Timur dan tujuan lain dari penelitian ini untuk mengetahui apakah terjadi flypaper effect pada daerah Kabupaten/Kota Provinsi Kalimantan Timur tahun 2010-2014. Alat analisis yang digunakan dalam penelitian ini adalah analisis regresi data panel. Hasil penelitian menjukkan bahwa pendapatan asli daerah (PAD) dan dan alokasi umum (DAU) berpengaruh signifikan terhadap belanja daerah. PAD berpengaruh signifikan terhadap belanja daerah namun DAU tidak berpengaruh signifikan terhadap belanja daerah. Selama periode penelitian tidak terjadi flypaper effect pada Kabupaten/Kota di Provinsi Kalimantan Timur.
\end{abstract}

Kata kunci: Pedapatan Asli Daerah (PAD), Dana Alokasi Umum (DAU), Belanja Daerah, dan Flypaper Effect

\section{PENDAHULUAN}

Indonesia telah memulai babak baru dalam kehidupan bermasyarakat sejak diberlakukannya kebijakan otonomi daerah yang tertera dalam Undang-Undang Nomor 32 Tahun
2004 tentang pemerintah daerah. Dengan adanya desentralisasi menurut Undang-Undang Nomor 32 Tahun 2004 bahwa dalam rangka penyelenggaraan pemerintah daerah sesuai dengan amanat Undang- 
Undang Dasar Republik Indonesia Tahun 1945, pemerintah daerah, yang mengatur dan mengurus sendiri urusan pemerintah menurut asas otonomi dan tugas pembantu, diarahkan untuk mempercepat terwujudnya kesejahteraan masyarakat melalui peningkatan, pelayanan, pemberdayaan, dan peran serta masyarakat, serta peningkatan daya saing daerah dengan memperhatikan prinsip demokratis, pemerataan, keadilan, keistimewaan dan kekhususan suatu daerah dalam sistem Negara Kesatuan Republik Indoensia.

Dalam pelaksanaanya, kebijakan otonomi daerah juga didukung dengan Undang-Undang Nomor 33 Tahun 2004 tentang Perimbangan Keuangan antara Pusat dan Daerah.

Wujud dari perimbangan keuangan antar pusat dan daerah diwujudkan melalui dana perimbangan yang bersumber dari APBN yang memang dialokasikan khusus kepada daerah untuk menyelenggarakan tugas daerah dalam rangka pelaksanaan desentarlisasi yang dibiayai atas beban APBD dimana Dana Perimbanga terdiri dari Dana Alokasi Umum
(DAU), Dana Alokasi Khusus (DAK) dan dana bagi hasil pajak / bagi hasil bukan pajak dari sumber daya alam. Ketiga jenis pendapatan tersebut dan Pendapatan Asli Daerah (PAD) merupakan sumber pendanaan utama yang digunakan bagi Pemerintah Daerah dalam rangka menyelenggarakan pemerintahannya sendiri. Dana bagi hasil berperan sebagai penyeimbang fiskal antar pusat dan daerah dari pajak yang dibagi. DAU berperan sebagai pemerata fiskal antar daerah (fiscal equilization) di Indonesia dan DAK berperan sebagai dana yang didasarkan pada kebijakan yang bersifat darurat (Saragih, 2003 dalam Kusumadewi, 2007). Tentunya penggunaan dana tersebut diserahkan sepenuhnya kepada pemerintah daerah yakni pemerintah kabupaten/kota yang diharapakan dapat menggunakan dana tersebut secara efektif dan seefisien mungkin guna meningkatkan pelayanan kepada masyarakat serta mempertanggungjawabkannya atas penggunaan dana tersebut.

Transfer pastinya harus dilaksanakan dalam pelasaknaan 


\section{Gambar 1. Grafik Kemampuan Daerah Kab/Kota di Provinsi Kalimantan Timur Tahun Anggaran 2010-2014 (dalam juta rupiah)}

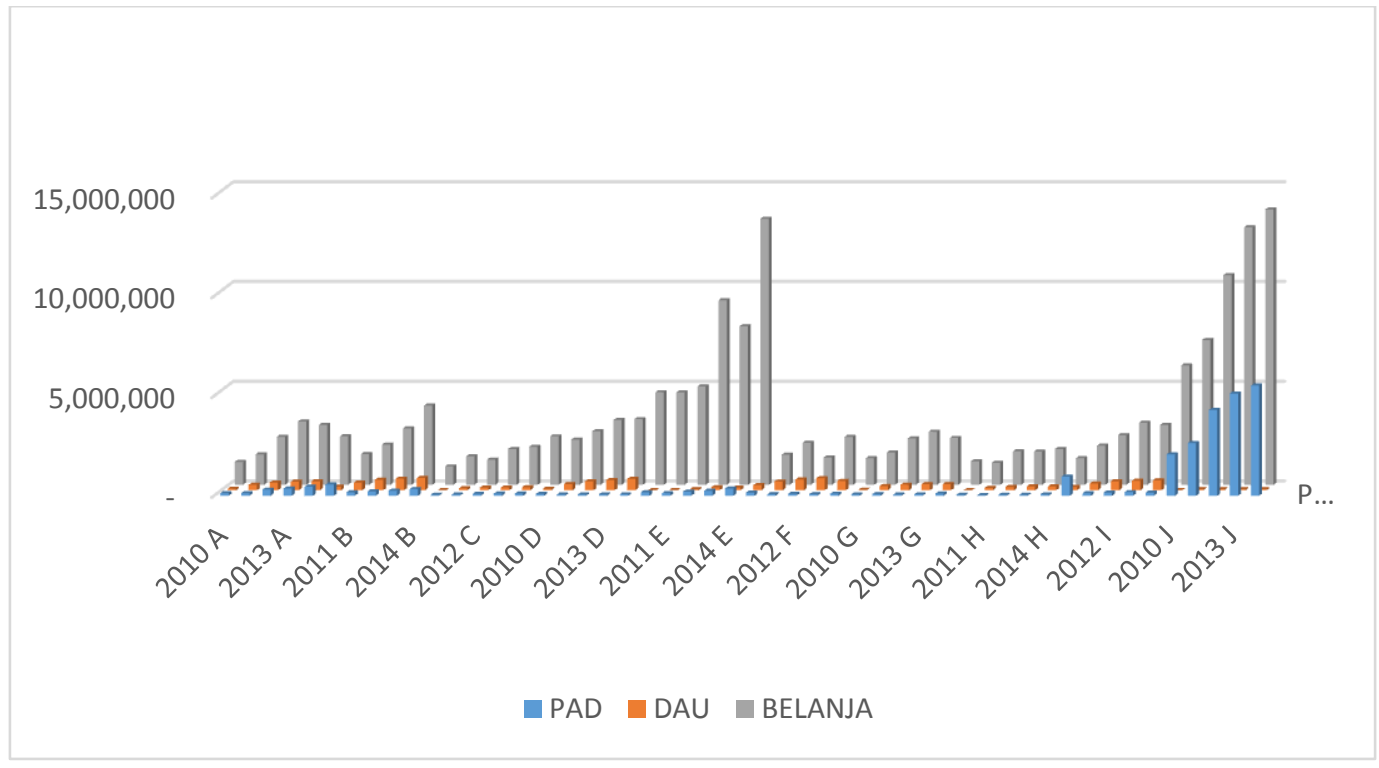

Sumber: Kemendagri, Perda Provinsi Kalimantan Timur, 2016

Keterangan:

$\mathrm{A}=$ Kota Balikpapan

$\mathrm{B}=$ Kota Samarinda

$\mathrm{C}=$ Kota Bontang

$\mathrm{D}=$ Kab. Kutai Timur

$\mathrm{E}=$ Kab. Kutai Kartanegara

$\mathrm{F}=\mathrm{Kab}$. Kutai Barat

$\mathrm{G}=\mathrm{Kab}$. Paser

$\mathrm{H}=\mathrm{Kab}$. Penajam Paser Utara

$\mathrm{I}=\mathrm{Kab}$. Berau

$\mathrm{J}=$ Provinsi Kalimantan Timur

desentralisasi karena pemerintah pusat melimpahkan wewenangnya kepada daerah dalam rangka menyelesaikan berbagai urusan pemerintahan yang dilimpahkan kepada pemda. Namun hal ini akan mengakibatkan adanya peningkatan pengeluran daerah dalam melaksanakan wewenangnya lebih banyak dibandingkan sebelum diberlakukannya otonomi daerah.

Namun pada praktiknya, transfer dari pemerintah pusat merupakan dana utama yang digunakan pemerintah daerah dalam pembiyaan utamanya sehari-hari, yang dilaporkan oleh pemda melalui perhitungan APBD. Ini dapat disebabkan oleh perbedaan penafsiran mengenai DAU oleh daerah-daerah. Menurut Saragih (2003) dalam Kusumadewi (2007), hal tersebut disebakan: (a) DAU merupakan hibah yang diberikan pemerintah pusat tanpa ada 
pengembalian, (b) DAU tidak perlu dipertanggungjawabkan karena DAU merupakan konsekuensi dari penyerahan kewenangan atau tugastugas umum pemerintah daerah, (c) DAU harus dipertanggungjawabkan baik ke masyarakat lokal maupun ke pusat, karena DAU berasal dari dana APBN.

Pada Gambar 1 yang mana menggambarkan kemampuan keuangan daerah kabupaten/kota di provinsi Kalimantan Timur. Bila melihat gambar di atas bahwa secara keseluruhan kabupaten/kota di Provinsi Kalimantan Timur memperoleh DAU yang setiap tahunnya terus bertambah. Gambar tersebut juga memperlihatkan bahwa belanja daerah kabupaten/kota di Kalimantan Timur setiap tahun anggarannya semakin cenderung meningkat namun masih mengalami fluktuasi pada daerah-daerah tertentu. Namun di sisi lain, kemandirian daerah yang dilihat dari segi indikator kontribusi PAD pada kabupaten/kota di Provinsi Kalimantan Timur cenderung meningkat pula di setiap kabupaten/kotanya. Dapat disimpulkan bahwa peningkatan DAU di kabupaten/kota di Provinsi
Kalimantan Timur membawa perubahan yang signifikan pada kemandirian daerah. Ini dibuktikan dari kontribusi PAD terhadap belanja daerah kabupaten/kota di provinsi Kalimantan Timur pada grafik mengalani perubahan yang berarti.

Adapun tujuan penelitian dari ini adalah untuk mengetahui pengaruh PAD dan DAU terhadap belanja di Provinsi Kalimantan Timur pada tahun 2010-2014. Dan juga untuk mengetahui terjadinya flypaper effect di Provinsi Kalimantan Timur pada tahun 2010-2014. Penelitian ini mengguankan 2 (dua) variabel independen dan 1 (satu) variabel dependent. Variabel indepeneden yang digunakan dalam penelitian ini adalah Pendapatan Asli Daerah (PAD) dan Dana Alokasi Umum (DAU) sedangkan variabel dependen yang digunakan dalam penelitian ini adalah Belanja Daerah.

Pendapatan Asli Daerah adalah pendapatan yang diperoleh daerah yang dipungut berdasarkan peraturan daerah sesuai dengan peraturan perundang-undangan. Yang mana PAD merupakan pendapatan yang bersumber dari hasil pajak daerah, hasil retribusi daerah, hasil 
pengelolaan kekayaan daerah yang dipisahkan, dan pendapatan daerah lain-lain yang sah, yang bertujuan untuk memberikan keleluasaan pada daerah dalam menggali pendanaan dalam pelaksanaan otonomi daerah sebagai perwujudan asas desentralisasi (Yani, 2002:51).

Cara menghitung dana alokasi umum berdasarkan ketentuan adalah sebagai berikut: 1). Dana Alokasi Umum (DAU) ditetapkan sekurangkurangnya $26 \%$ dari penerimaan dalam negeri yang ditetapkan dalam APBN. 2). Dana Alokasi Umum (DAU) untuk daerah propinsi dan untuk daerah kabupaten/kota ditetapkan masing-masing $10 \%$ dan 90\% dari dana alokasi umum sebagaimana ditetapkan diatas. 3). Dana Alokasi Umum (DAU) untuk suatu daerah kabupaten/kota tertentu ditetapkan berdasarkan perkalian jumlah dana alokasi umum untuk daerah kabupaten/kota yang ditetapkan APBN dengan porsi daerah kabupaten/kota yang bersangkutan. 4). Porsi daerah kabupaten/kota sebagaimana dimaksud di atas merupakan proporsi bobot daerah kabupaten/kota di seluruh Indonesia.
Menurut Kusumadewi (2007), Belanja daerah adalah semua pengeluaran kas daerah yang menjadi beban daerah dalam satu periode anggaran. Namun menurut UndangUndang Nomor 33 Tahun 2004 bahwa belanja daerah semua kewajiban daerah yang diakui sebagai pengurangan nilai kekayaan bersih dalam periode tahun anggaran yang bersangkutan.

Menurut Afrizawati (2012) flypaper effect merupakan respon yang tidak simetri atau asimetris terhadap peningkatan dan penurunan penggunaan dana transfer dari pemerintah pusat, yang mana masih menurut Afrizawati (2012) menyatakan bahwa dana transfer tersebut diberikan untuk jangka waktu tertentu dengan indikasi adanya pihak yang memperoleh keuntungan dari penerimaan transfer (grants) yang cenderung meningkat. Dengan kata lain penemuan flypaper effect pada alokasi pengeluaran, maka diharapakan pemerintah dapat seminimum mungkin memeperkecil respon yang berlebihan pada belanja daerah. Yang mana juga flypaper effect merupakan respon pemerintah 
daerah yang asimetris terhadap perubahan penggunaan transfer.

Beberapa kajian mengenai pelaksanaan desentralisasi di Indonesia sudah dilakukan oleh peneliti sebelumnya antara lain; Prakosa (2004), Masdjojo (2009),Herdiyanto (2014) dan Maimunah (2006). Para peneliti tersebut mengakaji pengaruh PAD dan DAU terhadap Belanja Daerah dengan mengambil sempel kabupaten/kota di Jawa Tengah, DIY, se-Indoensia dan Sumatera. Hasil penelitian menyimpulkan bahwa tidak semua PAD berpengaruh terhadap Belanja Daerah dan tidak semua PAD memiliki pengaruh terhadap Belanja Daerah dan tidak semua DAU mengalami flypaper effect. Provinsi Kalimantan Timur adalah provinsi yang berbeda dari yang diteliti peneliti sebelumnya yang memiliki karakteristik ekonomi dan geografi yang berbeda dengan pulau Jawa dan Sumatera. Keadaan yang berbeda inilah yang membuat peneliti ingin meneliti mengenai Analisis Flypaper Effect PAD Dan DAU Terhadap Belanja Daerah Di Provinsi
Kalimantan Timur Tahun 2010 2014.

Berdasarkan pada latar belakangsebelumnya maka dapat dirumuskan masalah sebagai yakni Bagaimana pengaruh PAD dan DAU terhadap belanja daerah di Provinsi Kalimantan Timur pada tahun 20102014 dan apakah terjadi flypaper effect di Provinsi Kalimantan Timur pada tahun 2010-2014.

\section{METODE PENELITIAN}

Jenis penelitian yang digunakan adalah analisis deskriptif kuantitatif dengan menggunakan data sekunder tahun 2010-2014 di Provinsi Kalimantan Timur, yakni terdiri dari 9 kabupaten/kota dengan yaitu: Kota Balikpapan, Samarinda, Bontang serta Kabupaten Kutai Timur, Kutai Kartanegara, Kutai barat, Paser, penajam Paser Utara, dan Beraudengan menggunakan data panel. Yang mana data panel yang merupakan gabungan dari data time series dan cross section. Teknik pengumpulan data yang digunakan dalam penelitian ini adalah teknik dokumentasi dari instansi pemerintahan terkait yaitu perda, kemendagri dan sumber-sumber terkait lainnya. 
Untuk menguji pengaruh PAD dan DAU terhadap Belanja Daerah, maka alat anlisis yang digunakan adalah Analisis Regresi Data Panel. Data panel atau pooled data merupakan kombinasi dari data time series dan cross section dengan persamaan sebagai berikut:

$\mathrm{BD}_{\mathrm{it}}=\mathrm{a}+\mathrm{b}_{1} \mathrm{PAD}_{\mathrm{it}}+\mathrm{b}_{2} \mathrm{DAU}_{\mathrm{it}}+\mathrm{e}_{\mathrm{it}}$

Dimana:

$\mathrm{BD}_{\mathrm{it}}=$ Jumlah belanja daerah $\left(\mathrm{BD}_{\mathrm{it}}\right)$

$\mathrm{A}=$ Konstanta

$\mathrm{B}_{1} \mathrm{~B}_{2} \mathrm{~B}_{3}=$ Koefisien regresi

PAD $_{\text {it }}=$ Jumlah PAD kabupaten $\mathrm{i}$ pada tahun $\mathrm{t}$

DAU $_{\text {it }}=$ Jumlah DAU kabupaten $\mathrm{i}$ pada tahun $\mathrm{t}$

$\mathrm{e}_{\mathrm{it}} \quad=$ Error term

Dengan mengakomodasi informasi baik yang terkait dengan variable-variabel cross section maupun time series, data pabel secara substansial mampu menurunkan masalah omitedvariabels, model yang mengabaikan variabel yang relevan (Wibisono, 2005 dalam Ajija, 2014).

Model regresi data panel ada 3 yaitu;common effect model (CEM), fixed effect model (FEM), dan random effect model (REM).

\section{PEMBAHASAN}

Hasil estimasi data panel dengan modelcommon effect,fixed effect, dan random effect berada dalam Tabel 1 . Pada tabel 1 bahwa pada regresi yang menggunakan modelcommon effect dapat diketahui bahwa jika nilai koefisien determinasi yang ditujukkan dengan R-squared adalah sebesar 29,89\%, ini menujukkan bahwa $29,89 \%$ variabel independen mampu dijelaskan oleh variabel indpenden dan 70,11\% sisanya dijelaskan oleh varibel lain. Dengan persamaan common effect adalah sebagai berikut:

Belanja $_{\text {it }}=1804085+7.107094 \mathrm{PAD}_{\text {it }}$

$$
-1.465213 \mathrm{DAU}_{\mathrm{it}}+\mathrm{e}_{\mathrm{it}}
$$

Berdasarkan pada tabel 1 bahwa pada regresi yang menggunakan modelfixed effect dapat diketahui bahwa jika nilai koefisien determinasi yang ditujukkan dengan R-squared adalah sebesar 91,67\%, ini menujukkan bahwa 91,67\% variabel independen mampu dijelaskan oleh variabel indpenden dan 8,33\% sisanya dijelaskan oleh varibel lain. Dengan persaam fixed effect adalah sebagai berikut: 
Belanja $_{\text {it }}=1111998+$

$1,823658 \mathrm{DAU}_{\mathrm{it}}+\mathrm{e}_{\mathrm{it}}$

\section{$5,493986 \mathrm{PAD}_{\mathrm{it}}+$}

Tabel 1. Hasil Regresi Data Panel

\begin{tabular}{|c|c|c|c|}
\hline Variabel & Common Effect & Fixed Effect & Random Effect \\
\hline Belanja & 4.380458 & 5.201331 & 2.262484 \\
\hline Prob. & $0.0001 *$ & $0.0000 * *$ & $0.0289 * *$ \\
\hline PAD & 4.231192 & 4.523992 & 4.901016 \\
\hline Prob. & $0.0001 * * *$ & $0.0001 * * *$ & $0.0000 * * *$ \\
\hline DAU & -1.266420 & 2.275132 & 1.996175 \\
\hline Prob. & 0.2123 & $0.0293 * *$ & 0.0525 \\
\hline R-squared & 0.298978 & 0.916717 & $\begin{array}{l}\text { (weighted) } \\
0.562912 \\
\text { (unweighted) } \\
0.185671\end{array}$ \\
\hline $\begin{array}{l}\text { Adjusted R- } \\
\text { squared }\end{array}$ & 0.265598 & 0.892222 & 0.542098 \\
\hline $\begin{array}{l}\text { Prob(F- } \\
\text { statistic) }\end{array}$ & 0.000576 & 0.000000 & 0.0000 \\
\hline F-statistic & 8.956254 & 37.4247 & 27.04525 \\
\hline$* * *$ & Signifikan $1 \%$ & & \\
\hline$* *$ & Signifikan 5\% & & \\
\hline$*$ & Signifikan $10 \%$ & & \\
\hline
\end{tabular}

Sumber: Eviews 6, data diolah, 2016

Berdasarkan pada tabel 1 bahwa pada regresi yang menggunakan modelrandom effect dapat diketahui bahwa jika nilai koefisien determinasi yang ditujukkan dengan R-squared pada weighted statistic adalah sebesar $56,29 \%$, ini nilai $\mathrm{R}$ squared pada unweighted statistics adalah sebesar bahwa 18,56\%. Dengan nilai Durbin-Watson statistik sebesar 1.987298 pada weighted dan
1.283717 pada unweighted statistics. Ini menujukkan bahwa 56,29\% variabel independen mampu dijelaskan oleh variabel indpenden dan $43,71 \%$ sisanya dijelaskan oleh varibel lain. Dengan persaanrandom effect adalah sebagai berikut:

Belanja $_{\text {it }}=1153342+5,739941$

$$
\begin{aligned}
& \text { PAD }_{i t}+1,547172 \text { DAU }_{i t} \\
& +\mathrm{e}_{i t}
\end{aligned}
$$

\section{Tabel 2. Hasil Regresi Uji Chow dan Hausman}

\begin{tabular}{llll}
\hline Model & Hipotesis & Prob & Status \\
\hline Uji Chow & $H_{0}=$ Common Effect & 0.0000 & $H_{0}=$ ditolak \\
& $H_{1}=$ Fixed Effect & & $H_{1}=$ diterima \\
\hline Uji Hausman & $H_{0}=$ Random Effect & 0.3378 & $H_{0}=$ diterima \\
& $H_{1}=$ Fixed Effect & & $H_{1}=$ ditolak
\end{tabular}

Sumber: Eviews 6.0, data diolah, 2016 
Pemilihan Model Terbaik Regresi Data Panel

Adapun hasil pengujian untuk uji chow dan hausman yang diperoleh dapat dilihat pada tabel 2.Berdasarkan hasil pengkajian pada tabel 2 maka terlihat bahwa nilai probabilitas cross section F pada uji chow sebesar 0,0000 sehingga dapat diketahui bahwa nilai tersebut lebih kecil dari 0,05 sehingga menolak $\mathrm{H}_{0}$ dan menerima $\mathrm{H}_{1}$ maka dapat disimpulkan bahwa estimasi menggunakan model common effect ditolak yang artinya model yang lebih baik adalah model random effect.

Hasil uji hausman terlihat bahwa nilai probabilitas cross sectionrandom effect sebesar 0,3378 sehingga dapat diketahui bahwa nilai tersebut lebih besar daro 0,05 sehingga menolak $\mathrm{H}_{1}$ dan menerima $\mathrm{H}_{0}$ yang berarti menolak fixed effect dan meriman random effect.

Jika uji chow dan uji hausman telah dilakukan maka dapat ditentukan model yang terpilih adalah uji hausman dengan model random effect sebagai model terbaik.

Hasil pengujian regresi dengan model random effect menjukkan jika variabel yang berpengaruh signifikan karena nilai signifikan $\mathrm{t}$-statistik kurang 0,05 yaitu variabel PAD (prob: 0,0000) dan DAU tidak signifian (prob: 0,0524).

\section{Penentuan flypaper effect}

Untuk menentukan terjadi atau tidaknya flypaper effect maka peneliti menggunakan pendekatan flypaper effect yakni menggunakan perbandingan antra koefisen PAD dan koefisien DAU. Jika koefisien DAU > Koefisien PAD maka terjadi flypaper effect, atau bisa juga dapat difungsikan jika b1 > b2, berarti $\frac{b 1}{b 2}>$ 1 maka terjadi flypaper effect. Maka : $\frac{\text { koefisien } D A U}{\text { koef isien } P A D}=\frac{1.45712}{5.73894}=0,2696$

Untuk mengetahui ada atau tidaknya terjadi flypaper effect, maka DAU tentunya harus memiliki pengaruh yang lebih kuat dari pada PAD. Berdasarkan hasil dari perhitungan flypaper effect sebelumnya maka dapat dikatakan bahwa tidak terjadi flypaper effect karena koefisien DAU < koefisien PAD dengan $1,54712<5.73894$. Dan hasil dari perhitungan Koefisien DAU/PAD adalah $0,2061<1$. Sesuai dengan hipotesis maka $H_{1}$ ditolak dan menerima $H_{0}$ karena hasilnya 
$0,2696<1$. Provinsi Kaliamantan

Timur tidak terjadi flypaper effect.

\section{Hubungan PAD dan DAU}

\section{Terhadap Belanja Daerah}

Berdasarkan hasil penelitian melalui uji hasil bahwa dapat dikatakan hubungan PAD dan DAU terhadap belanja daerah memiliki hubungan yang signifikan positif. Variabel tersebut memiliki peran yang cukup andil dalam belanja daerah dilhat dari hasil regresi koefisien yang signifikan positif terhadap belanja daerah. Kabupaten kota di Kalimantan Timur belanja daerah setiap tahunnya semakin meningkat. Meningkatnya belanja bisa dikarena berbagai hal, misalnya seperti penambahan grants (transfer), transfer ini dapat berupa DAU, DAK, DBH tentunya juga itu termasuk dalam bagian dana perimbangan dana perimbangan. Jika PAD meningkat tentunya juga akan membuat belanja daerah pun meningkat. Karena dengan semakin meningkatnya pendapatan atau pemasukan maka pengeluaran pun juga akan semakin bertambah, seperti halnya yang juga terjadi di Provinsi Kalimantan Timur.
Hasil pengujian ini mendukung dengan hasil pengujian Herdiyanto (2014), Prakosa (2004), Maimunah (2006), Kusumadewi (2007) bahwa PAD dan DAU berpengaruh signifkan terhadap belanja daerah, sehingga dapat mendukung penelitian ini.

\section{Pengaruh PAD Terhadap Belanja} Daerah

Tentunya pengaruh PAD terhadap belanja daerah berdasarkan hasil analisis bahwa berpengaruh signifikan positif. PAD di Provinsi Kalimantan Timur memiliki nilai yang cukup besar. Sehingga dengan meiliki pendapatan sendiri maka pemerintah bebas menggunakan dana tersebut baik itu untuk belanja daerah, pun untuk keperluan pembangunan, atau pun untuk investasi daerah. Tentunya dengan menghasilkan PAD yang tinggi daerah dapat lebih memaksimalkan lagi untuk meningkatkan sumbersumber keuangan daerahnya untuk digali lagi.

Hamdani (2014), menjelaskan bahwa hubungan antara dan proporsi pendapatan dan dan konsumsi mendekati proporsional, artinya jika pendpatan meningkat maka tentunya secara proporsional konsumsi pun 
jug akan meningkat sebaliknya jika pendapatan menurun maka konsumsi pun akan menurun pula.

Hasil pengujian ini di dukung dengan penelitian Maimunah (2006), Hamdani (2014), Masdjojo (2009) dan Herdiyanto (2014) bahwa PAD berpengaruh positif terhadap belanja daerah di Provinsi Kalimantan Timur dapat diterima.

\section{Pengaruh DAU Terhadap Belanja Daerah}

Berdasarkan hasil analisis DAU tidak pengaruh terhadap belanja daerah di Provinsi Kalimantan Timur Kaliamntan. Hasil penelitian ini juga didikung dengan Herdiyanto (2014) bahwa DAU berpengaruh signifian negatif terhadap belanja daerah dapat diterima. Hasil yang tidak signifkan ini bisa jadi karena oleh jumlah data yang kosong, yaitu DAU Kutai Kartanega tahun 2010 dan tidak sebegitu besarnya DAU yang diterima oleh kab/kota di Provinsi Kalimantan Timur.

\section{Flypaper Effect}

Flypaper effect merupakan suatu kondisi keuangan pemerintah daerah yang membelanjakan lebih banyak atau lebih boros menggunakan dana transfer atau DAU daripada menggunakan dana sendiri atau PAD (Hamdani, 2014). Tentunya untuk menetukan terjadi flypaper effect maka harus membandingkan koefisien DAU dengan koefisien PAD.Dilihat dari hasil koefisien PAD yang lebih besar dari pada DAUyang mana DAU < koefisien PAD dengan nilai $1,54712<$ 5.73894dan hasil dari perhitungan Koefisien DAU/PAD adalah 0,2061 < 1. Maka di Provinsi Kalimantan Timur tidak terjadi flypaper effect. Ini menjukkan bahwa Kaltim termasuk daerah yang mandiri karena lebih banyak menggunakan PAD dari pada DAU untuk belanja daerah. Maka dapa dikatakan bahwa Provinsi Kalimantan Timur memiliki keuangan daerah yang cukup baik, ini menjukkan Kalimantan Timur tidak memiliki pola ketergantungan. Dengan demikian kondisi keuangan dapat dikatakan cukup baik.

Hasil penelitian ini sesuai dengan penelitian Herdiyanto (2014) bahwa DAU tidak bepengaruh signifkan terhadap belanja daerah di Provinsi Kalimantan Timur dibuktikan dengan nilai koefisien PAD terhadap belanja daerah yang lebih besar daripada koefisien DAU dapat diterima. 


\section{PENUTUP}

Berdasarkan hasil pengujian dan analisis deskriptif, diperoleh bebrapa hal bahwa;1). PAD berpengaruh signifikan positif terhadap belanja daerah. Hal ini dapat dilihat berdasarkan signifikan pada seluruh kabupaten/kota di Provinsi Kalimantan Timur. Hal ini dapat dilihat berdasarakan nilai probabilitas t-statistic yaitu sebesar $0,0000<0,05(\alpha=5 \%)$ yang berarti bahwa PAD berpengaruh terhadap belanja daerah. 2). DAU berpengaruh negatif terhadap belanja daerah. Hal ini dapat dilihat berdasarkan signifikan di Provinsi Kalimantan Timur. Hal ini dapat dilihat berdasarakan nilai probabilitas $\mathrm{t}$ statistic yaitu sebesar $0,0525>0,05$ $(\alpha=5 \%)$ yang berarti bahwa DAU tidak berpengaruh terhadap belanja daerah. 3). PAD dan DAU berpengaruh positif terhadap belanja daerah. Hal ini dapat dilihat berdasarkan probabilitas t-statistic yaitu sebesar $0,0289<0,05(\alpha=5 \%)$ yang berarti bahwa PAD dan DAU berpengaruh terhadap belanja daerah. 4). PAD dan DAU terbukti mempengaruhi Belanja Daerah secara signifikan dan postif, namun tidak mengalami flypaper effect dikarenakan koefisien PAD > koefisien DAU atau DAU/PAD tidak lebih besar dari pada satu. belum termasuk daerah yang mandiri. Dengan demikian bahwa hasil $0,2696<1$, dengan begitu menolak $\mathrm{H} 1$ dan menerima $\mathrm{H}_{0}$. Maka di Provinsi Kalimantan Timur tidak terjadi flypaper effect karena nilai kurang dari 1 atau koefisien DAU lebih kecil dari ada koefisien PAD. 5). Dari hasil penelitian ini maka dapat dikatakan bahwa Provinsi Kalimantan Timur tidak mengalami flypper effect namun hasil ini hanya dapat diterapkan di Provinsi Kalimantan Timur dan tidak dapat diterapkan di daerah lainya.

Sebaiknya pemerintah Daerah Provinsi Kalimantan Timur semestinya selalu berinovasi dalam hal pengelolaan keuangan untuk meningkatkan PAD melalui dana transfer berupa DAU yang merupakan salah satu sumber belanja daerah. Melalui penggalian Pendapatan Asli Daerah sebagai sumber keuangan daerah Provinsi Kalimantan Timur dapat menjadi daerah yang mandiri dan tidak ketergantungan terhadap dana 
transfer dari pusat terhadap belanja daerah. Dan juga pemerintah pusat berkewajiban lebih mendorong pemerintah daerah dalam mengelola keuangannya dengan baik agar tetap tidak tejadi flypaper effect. Dengan demikian pemerintah daerah akan berusaha meningkatkan pendapatan asli daerah, PAD akan menjadi sumber keuangan utama daerah bukan dana transfer sebagai sumber utama dalam melakukan belanja daerah.

\section{DAFTAR PUSTAKA}

Afrizawati. 2012. Analisis Flypaper Effect Pada Belanja Daerah Kabupaten/Kota Di Sumatera Selatan. Jurnal Ekonomi dan Informasi (JENIUS) 2: 21-30.

Ajija, S.R., D. Wulansari., R.H. Setianto, dan M.R. Primanthi. 2014. Cara Cerdas Menguasai Eviews. Salemba Empat. Jakarta.

Hamdani, S., S. Mintarti, A. Setyawati. 2014. Pengaruh Dana Alokasi Umum (DAU) dan Pendapatan Asli Daerah (PAD) Pada Kabupaten/Kota Di Provinsi Kalimantan Timur.

Herdiyanto, L., dan S. Rahayu. 2014. Flypaper Effect Pada Dana Alokasi umum dan Pendapatan Daerah terhadap Belanja Daerah Pada Kota Bandung Periode 2008-2012. 1-11.
Kemendagri. Data Anggaran Pendapatan Dan Belanja Daearah Tahun Anggaran 2011. Permendagri. 2011. Jakarta.

Kemendagri. Data Anggaran Pendapatan Dan Belanja Daearah Tahun Anggaran 2013. Permendagri. 2013. Jakarta.

Kemendagri. Data Anggaran Pendapatan Dan Belanja Daearah Tahun Anggaran 2014. Permendagri. 2014. Jakarta.

Kusumadewi, D.A., dan A. Rahman. 2007. Flypaper Effect Pada Dana Alokasi Umum (DAU) Dan Pendapatn Asli Daerah (PAD) Terhadap Belanja Daerah (BD) Pada Kabupaten / Kota di Indonesia. JAAI 11(1): 67-80.

Maimunah, M. 2006. Flypaper Effect Pada Dana Alokasi Umum (DAU) dan Pendapatan Asli Daerah (PAD) Terhdap Belanja Daerah Pada Kabuapten / Kota di Pulau Sumatra. Simposium Nasional Akuntansi 9 Padang 1-27.

Masdjojo, G.N., dan Sukartono. 2009. Pengaruh Pendapatan Asli Daerah dan Dana Perimbangan Terhadap Belanja Daerah Serta Analisis Flypaper-Effect Kabupaten / Kota Di Jawa Tengah Tahun 2006-2008. TEMA Telaah Manajemen 6(1): 32-50. 
Prakosa, K.B. 2004. Analisi Pengaruh Dana Alokasi

Umum (DAU) dan
Pendapatan Asli Daerah (PAD) Terhadap Prediksi Belanja Daerah Studi Kasus Provinsi Jawa Tengah dan DIY. JAAI 8(2): 104-107.

Undang-Undang Republik Indonesia Nomor 32 Tahun 2004. 15 Oktober 2004. Pemerintah Daerah. Jakarta.

Undang-Undang Republik Indonesia Nomor 33 Tahun 2004.15 Oktober 2004. Perimbangan Keuangan Antar Pemerintah Pusat dan Daerah. Jakarta.
Undang-Undang Republik Indonesia Nomor 28 Tahun 2009. 15 September 2009. Pajak Daerah dan Retribusi Daerah. Jakarta.

Undang-Undang Republik Indonesia Nomor 28 Tahun 2006. 24 Februari 2006. Pajak Daerah dan Retribusi Daerah. Jakarta.

Yani, A. 2002. Hubungan Keuangan Antara Pemerintah Pusat Dan Daerah Di Indonesia: Edisi Revisi. PT. Rajagrafindo Persada. Jakarta. 